\title{
The incorporation of undergraduate academy students from a public university to the productive sector with substance in its professional competences
}

\section{La incorporación de los estudiantes de contaduría de pregrado de una universidad pública al sector productivo con sustento en sus competencias profesionales}

\author{
ARGÜELLES-MA, Luis Alfredo $\dagger^{*}$, QUIJANO-GARCIA, Román Alberto, MEDINA-BLUM, \\ Fernando and CRUZ-MORA, Carlos Enrique
}

Universidad Autónoma de Campeche. Av. Agustín Melgar S/N, Col. Buenavista C.P. 24039 Campeche, Campeche, México.

ID $1^{\text {st }}$ Author: Luis Alfredo, Arguelles-Ma / ORC ID: 0000-0003-0315-4585, Researcher ID Thomson: S-5454-2018, CVU CONACYT ID: 300184

ID $1^{\text {st }}$ Coauthor: Román Alberto, Quijano-Garcia / ORC ID: 0000-0001-7316-1997, Researcher ID Thomson: G-60142018, CVU CONACYT ID: 485854

ID $2^{\text {nd }}$ Coauthor: Fernando, Medina-Blum / ORC ID: 0000-0001-6532-0871, Researcher ID Thomson: M-1632-2017

ID $3^{\text {rd }}$ Coauthor: Carlos Enrique, Cruz-Mora / ORC ID: 0000-0003-2070-7938

DOI: $10.35429 /$ JSETM.2019.4.3.20.28

Received January 21, 2019; Accepted June 28, 2019

\begin{abstract}
The university vision envisages the training of students with professional skills for their timely inclusion through recruitment mechanisms in the productive sector, establishing their policies of entry, training and egress. For this purpose this longitudinal descriptive research is carried out at a Public University with two cohorts, 2018 and 2019, there are 192 undergraduate students of the Bachelor's Degree in Accounting, 93 of 2018 and 99 of 2019. respectively, who are in the last semester, to determine whether the process of adopting competences is satisfactory to interfere with the productive processes of organizations. Using a valid and reliable instrument it is determined that the predominant female population predominates with $53.8 \%$ for 2018 and $56.6 \%$ for 2019, in addition that in maximum Likert scale the result shows that by 2018 the average is 4.5484 meaning that they feel competent for in curbing their incorporation into work by decreasing slightly by 2019 to 4,5357 ; contrasts significantly with the perception they have for inclusion in the workplace since by 2018 the average is 4,5161 , decreasing by 2019 to 4.2222. Although there is a confidence picture, it will have to monitor the next results by the declining trend that is observed.
\end{abstract}

Public university, Professional skills, Productive sector

\begin{abstract}
Resumen
La visión universitaria contempla la formación de estudiantes con competencias profesionales para su inclusión oportuna mediante mecanismos de contratación en el sector productivo, estableciendo sus políticas de ingreso, formación y egreso. Con este propósito se realiza esta investigación descriptiva longitudinal en una Universidad Pública con dos cohortes, 2018 y 2019, son 192 estudiantes de pregrado de la Licenciatura en Contaduría, 93 del 2018 y 99 del 2019, respectivamente, que cursan el último semestre, para determinar si el proceso de adopción de competencias es satisfactorio para inmiscuirse en los procesos productivos de las organizaciones. Utilizando un instrumento válido y confiable se determina que predomina la población femenina con $53.8 \%$ para 2018 y $56.6 \%$ para 2019 , además que en escala Likert máxima de 5 el resultado arroja que para 2018 la media es de 4.5484 significando que se sienten competentes para enfrentar su incorporación al trabajo disminuyendo levemente para 2019 al alcanzar 4.5357; contrasta sensiblemente con la percepción que tienen para su inclusión en el ámbito laboral toda vez que para 2018 la media es 4.5161, disminuyendo para 2019 al 4.2222. Aunque existe un panorama de confianza, habrá de monitorear los próximos resultados por la tendencia de disminución que se observa.
\end{abstract}

Universidad pública, Competencias profesionales, Sector productivo

Citation: ARGÜELLES-MA, Luis Alfredo, QUIJANO-GARCIA, Román Alberto, MEDINA-BLUM, Fernando and CRUZMORA, Carlos Enrique. The incorporation of undergraduate academy students from a public university to the productive sector with substance in its professional competences. Journal Schools of economic Thought and Methology. 2019. 3-4: 2028.

\footnotetext{
* Correspondence to Author (email: luisarguellesmaa@ hotmail.com)

$\dagger$ Researcher contributing as first author.
} 


\section{Introduction}

Globalization has had a significant impact on society since it undergoes transformations in its fundamental scenarios, within them is the educational one where it is necessary to define and acquire important features that had not been taken into account before, we must continually adapt to changes social, intertwining the theoretical field with the professional and work reality, promoting individual development without prejudice to multiculturalism, promoting active participation, innovation and entrepreneurship within a competitive framework in all aspects.

What is evident is that the insertion of nascent techniques, as well as of integrating new scientific advances in order to give a higher index of productivity is necessary in the innovation of the productive processes, although it is necessary to emphasize the study, analysis and management of social capital policies, in search of the development of the human resource contributing to the knowledge of the management and use of the inputs, leading to improve the participation within the organization of all those involved (Ibarra, 2000).

The transformation and innovation is also reflected in the University, being an important actor in society, which motivates this investigation of the situation that prevails between the labor insertion of students close to being part of the productive life of the country and competences that are provided and amalgamated during the educational process.

The economic conditions of the country have changed as new knowledge was used; The production, distribution and management are being impacted, leading to new practices of life and consumption of the population. The social and work environment influenced by the knowledge revolution and the development of information technology and communication has led to the need to narrow the gap between education and the world of work in order to ensure that students graduate have a set of appropriate knowledge and that they respond to what is needed to act in reality.
Acquiring the knowledge and capacity of its application depends on the individual characteristics of each person and the responsibility of the educational institutions is to provide an educational practice where the education by the educator is adequate and the student acquires the appropriate learning to integrate to the productive apparatus.

The main objective of the educational practice is to give a comprehensive training to the student with sufficient preparation for their transformation and integration with society, through the skills to be productive (Argudín, 2007).

Then, the new tendency to create knowledge, which is known as competitionbased education, that maintains a growing trend across the globe takes momentum; in more colloquial terms, and seen from this approach, the relevance is given to the use made of knowledge, and not the learning that is had of them. (Verdejo, 2006).

Thus, the development of competences implies a close collaboration between what an individual contributes to the work process and what the organization can facilitate for the development of their competences, the training must also be extended in addition to the professional life contexts to the incorporation of experiential, contextual elements and of own activities that resulted as part of the application of the skills acquired in solving problems in the workplace (Mertens, 1998), as mentioned by this author, within the production process and the completion of a task in Specific is not only composed of applying the learning acquired at the time of training and teaching a certain responsible, but this knowledge is concretized with carrying out the assigned work practice, thus creating a firm competence in which it can be developed.

In this study it is possible to establish a link between the attitudes of the students towards their employability and the ability to obtain a job that allows them to integrate under the support of the professional competences (training) acquired in the classroom. 


\section{Theoretical framework}

The greater current complexity of the economic scenario causes companies to begin to experience problems with policies and practices of all kinds from the executive to the productive and at all hierarchical levels of organizations, which until then had allowed them to have an acceptable development in the market; As a result of this complexity, the productive sector had the need to rethink the models they implemented in the development of the productive processes in order to maintain themselves.

The management of human capital begins with a model of skills, over time and through behavioral evaluations it is able to be profiled towards the qualification of tasks, and that these are empirically verified, thus the profiling profile begins in the 70s in various countries of Europe and Latin America, highlighting to some extent Mexico in the conceptual elaboration and practical application of the emerging model.

This new model was becoming important and a great diversity of concepts emerged regarding it. It is imperative to mention that the skills become a bunch of attitudes, skills and behaviors that certain individuals can handle better than others, becoming efficient and effective in certain situations.

These competences are verifiable in the work performance and in certain situations of study, in which they are put into practice, all of them depending on the tests applied. It is then that it is possible to mention that the competences are shaped by the individual traits of the people and the qualities that require said task or function to be carried out in a specific job (Leboyer, 1997).

For (Tejada, 1999), knowing how to be, knowing how to do and knowing how to be, can be a synonym as a whole of the competences at a level of global analysis of a person, together with their attitudes, aptitudes, knowledge and practices learned; All this in perfect integration. Mastering all the aforementioned results from a capable, effective, efficient and productive individual in a professional work situation.
A fully globalized scenario and the repeated technological evolution of the markets oblige the university to keep in agreement, providing suitable graduation profiles and with a high capacity for its incursion in the productive sector, Blanco (2005) continues indicating that the changes that have come mentioning have resulted in a labor market that could be considered as differentiated, globalized and specialized, where factors that avoid job stagnation and static employment in graduates in a nascent professional work career coexist.

Entering the productive sector becomes complex, insertion is difficult. Consequently, accessing a job becomes more complex, being an important part of this process the labor insertion where it is defined in obtaining a job and developing it, part where the competences acquired during university education, Fournet, play a preponderant role. (1993) states that at the moment the insertion issue is touched upon, this is often confused with the decision to enter a job and get the first job, rather it is a whole project planned from a long time ago, that is to say, it is not an event that lasts only a few moments, but it becomes a process of slow progress and with many decision making along the way.

A combination of several factors is involved in labor insertion (Bisquerra, 1992), which will depend on the characteristics of each individual, as well as on job opportunities within the market, with a clash between the level of employment and the occupancy level. The labor insertion is a reflection of the interaction between the competences and the adjustment of occupation of the academic applicants in a defined social context (Blanco, 2005), employing a person maintains a vision totally in the person and in the way in which this one learns, on the other hand, to occupy it is according to the context of it. Under this perspective, the university is emerging to fulfill its social responsibility by guaranteeing quality training, in accordance with technical, scientific and artistic knowledge, crossing borders for the configuration of an integral entity that responds to the social demands of the 21 st century; The challenge is the permanent evolution so that graduates are armed with the educational platform that supports their competence before the community taking into account all internal and external factors to him and the institution. 


\section{Methodology}

The research is of a longitudinal descriptive type, since the students under study were evaluated and analyzed for a prolonged period of time (Myers, 2006). Visser (1985, cited in Arnau $\&$ Bono, 2008) defines it as the examination of changes produced over time in the same sample, in a non-experimental descriptive design, not attempting to modify the study variables but to determine the characteristics of perception on the inclusion in the productive sector based on the professional skills of undergraduate students of a public institution in the State of Campeche. Therefore, it begins with the determination of the characteristics of the sample under study, through: The analysis of their attitudes and beliefs towards employment and the degree of perception regarding the acquisition of professional skills, and to establish sustainability between both. Of the 20 assertions that make up the dimension attitudes and beliefs towards employment, 8 are selected, which are those that have a direct relationship with the labor insertion: 1.- Finding a job is important for me, 2.-I feel qualified to look for a job , 3.-Job search techniques help to find work, 4.-Job search is pleasant, stimulating and challenging, 5.-I know the sources that can provide me with a job, 6.-I feel qualified to use employment techniques properly, 7.-I would like to have a paid job, even if the money is not needed and 8.-Work is the most important activity of a person, the remaining 12 complement the statistical study. Questionnaires are used to collect data directly, a method considered quantitative by Hernández et al. (2010).

The research focused on undergraduate students of the Autonomous University of Campeche of the Bachelor of Accounting, and who were studying the last degree of the degree, in the cohorts corresponding to the years 2018 and 2019. The total number of participants taken in Census form was 93 for the year 2018 and 99 for 2019 making a grand total of 192 students surveyed. See Table 1.

\begin{tabular}{|r|r|r|r|}
\hline \multicolumn{1}{|c|}{ Cohort } & \multicolumn{1}{|c|}{ Population } & \multicolumn{1}{c|}{ Sample } & Percentage \\
\hline 2018 & 93 & 93 & 48.40 \\
\hline 2019 & 99 & 99 & 51.60 \\
\hline Total & 192 & 192 & $100.00 \%$ \\
\hline
\end{tabular}

Table 1 Students surveyed of the Bachelor of Accounting in Cohorts 2018 and 2019

Source: own elaboration
The structure of the questionnaire used in the data collection consists of 4 dimensions of which 2 were used for the present study: 1 . Orientation of labor advice and transversal competences; and 2. Attitudes and beliefs towards employment in particular those related to establishing the inclusion in the productive sector supported by their professional competences of undergraduate students in the accounting degree of a Public University in Campeche. The instrument is made up of 50 questions of which a total of 33 were submitted to the study analysis, consisting of 20 of the "Attitudes and beliefs towards employment" dimension and 13 referring to the "Professional competencies" section of the "Counseling guidance" dimension labor and transversal competencies "with a structure on a Likert-type scale, with five response options: nothing $=1$, little $=2$, something $=3$, enough $=4$, a lot $=5,2$ dichotomous items that refer to the" Search for employment "such as age and gender. See table 2.

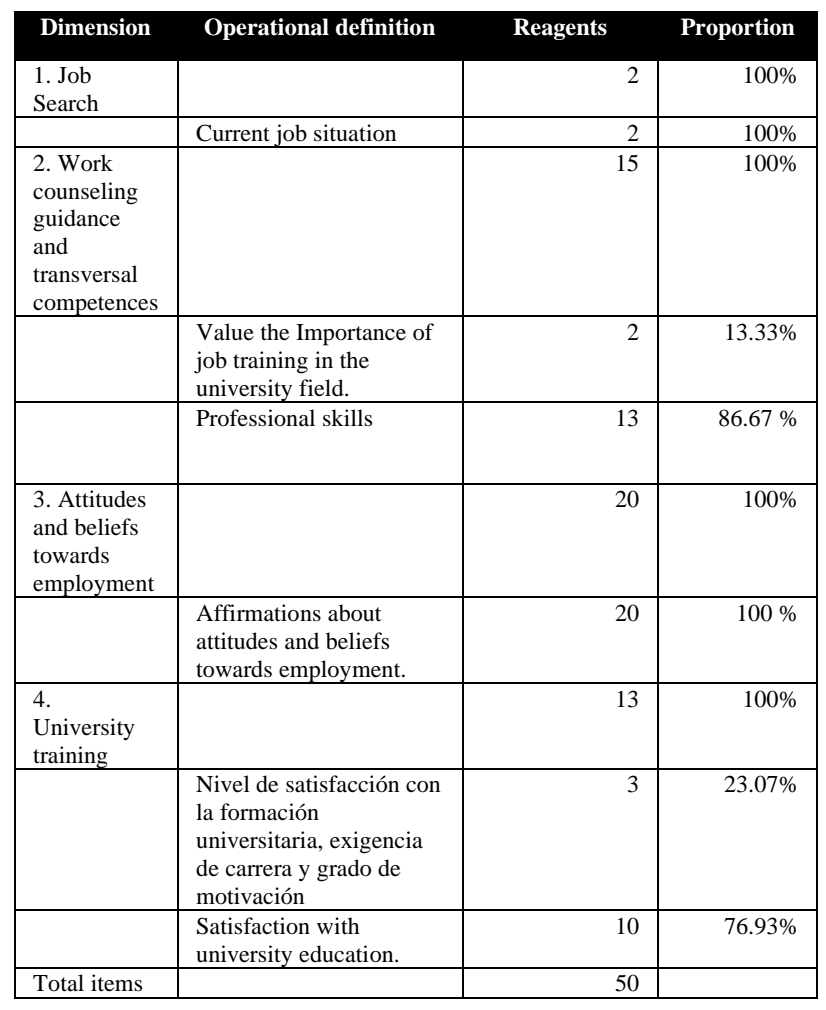

Table 2 Structure of the Accounting Degree questionnaire Source: self made 
The reliability of the "Professional competencies" section of the "Employment counseling guidance and transversal competencies" dimension and the "Attitudes and beliefs towards employment" dimension under study by the internal consistency factor of Cronbach's alpha is determined according to its cohort structure, undergoing the SPSS statistical system process (v.23). Regarding the structure of the section "Professional competences" of the dimension "Guidance on labor advice and transversal competences", it consists of 13 items. See Table 3.

\begin{tabular}{|l|r|r|}
\hline \multicolumn{1}{|c}{ Dimension } & Items & Percentage \\
\hline Total reagents section & 13 & $100 \%$ \\
\hline $\begin{array}{l}\text { Professional } \\
\text { competences for a } \\
\text { degree in Accounting }\end{array}$ & 13 & $100 \%$ \\
\hline
\end{tabular}

Table 3 Structure of the section "Professional competences" of the dimension "Orientation of labor advice and transversal competences" of the Bachelor of Accounting

Source: self made

Structure of the section "Professional competences" of the dimension "Orientation of labor advice and transversal competences" of the Bachelor of Accounting. Source: Own elaboration Structure of the section "Professional competences" of the dimension "Orientation of labor advice and transversal competences" of the Bachelor of Accounting. Source: self made.

\begin{tabular}{|l|r|r|}
\hline \multicolumn{1}{|c}{ Dimension } & Items & Percentage \\
\hline Total reagents section & 20 & $100 \%$ \\
\hline $\begin{array}{l}\text { "Attitudes and beliefs } \\
\text { towards employment" }\end{array}$ & 20 & $100 \%$ \\
\hline
\end{tabular}

Table 4 Structure of the dimension of "Attitudes and beliefs towards employment" of the Bachelor of Accounting

Source: self made

In order to establish the reliability of the results, Cronbach's alpha obtained for the 2018 cohort in the "Professional competencies" section of the "Employment counseling and transversal competencies" dimension turns out to be completely reliable as indicated by the value of 0.927 , in contrast to the 0.642 value for the 2019 cohort is questionable. See Table 5.

\begin{tabular}{|l|r|r|r|}
\hline \multicolumn{2}{|c|}{$\begin{array}{c}\text { Number of } \\
\text { elements }\end{array}$} & \multicolumn{1}{c|}{$\begin{array}{c}\text { Alfa de } \\
\text { Cronbach } \\
\mathbf{2 0 1 8}\end{array}$} & $\begin{array}{c}\text { Alfa de } \\
\text { Cronbach } \\
\mathbf{2 0 1 9}\end{array}$ \\
\hline $\begin{array}{l}\text { Total reagents } \\
\text { section }\end{array}$ & 13 & & \\
\hline $\begin{array}{l}\text { Professional } \\
\text { competences for } \\
\text { the Bachelor of } \\
\text { Accounting }\end{array}$ & 13 & 0.927 & 0.642 \\
\hline
\end{tabular}

Table 5 Reliability analysis of the reagents of the structure of the section "Professional competences" of the dimension "Guidance for labor advice and transversal competencies" of the Bachelor of Accounting in 2018 and 2019

Source: own elaboration

Regarding the reliability of the results of the "Attitudes and beliefs towards employment" dimension in the 2018 and 2019 cohorts, they are poor with values of 0.428 and 0.407 respectively. So the results are unreliable. See table 6 .

\begin{tabular}{|l|r|r|r|}
\hline \multicolumn{2}{|c|}{$\begin{array}{c}\text { Number of } \\
\text { elements }\end{array}$} & $\begin{array}{c}\text { Alfa de } \\
\text { Cronbach } \\
\mathbf{2 0 1 8}\end{array}$ & $\begin{array}{c}\text { Alfa de } \\
\text { Cronbach } \\
\mathbf{2 0 1 9}\end{array}$ \\
\hline Total reagents section & 20 & & \\
\hline $\begin{array}{c}\text { "Attitudes and beliefs } \\
\text { towards employment" }\end{array}$ & 20 & 0.428 & 0.407 \\
\hline
\end{tabular}

Table 6 Reliability analysis of the reagents of the structure of the "Attitudes and beliefs towards employment" dimension of the Bachelor of Accounting in 2018 and 2019

Source: own elaboration

The distribution by age ranges with the highest presence in both cohorts is between 21 23 years, $87(93.5 \%)$ in the 2018 cycle and 85 $(89.58 \%)$ in 2019 making a grand total of 172 people representing $89.58 \%$ of the surveyed students, this result was to be expected as students of the last semester of the undergraduate degree in accounting, in second term More than 23 years with a total of 17 $(8.88 \%)$ people of both cycles and finally the 18 - $203(1.56 \%)$ of the grand total. See Table 7.

\begin{tabular}{|c|r|r|r|r|r|r|}
\hline $\begin{array}{c}\text { AGE } \\
\text { RANGES }\end{array}$ & \multicolumn{1}{c}{ CYCLE 2018 } & \multicolumn{1}{c|}{ CYCLE 2019 } & \multicolumn{2}{c|}{ TOTAL } \\
POPULATION & POPULATION & \multicolumn{1}{c|}{ POPULATION } & $\%$ \\
\hline $18-20$ & 1 & 1.1 & 2 & 2.0 & 3 & 1.56 \\
YEARS & & & & & & \\
\hline $21-23$ & 87 & 93.5 & 85 & 85.9 & 172 & 89.58 \\
YEARS & & & & & & \\
OLD & & & & & & \\
\hline $\begin{array}{c}\text { OVER } \\
23\end{array}$ & 5 & 5.4 & 12 & 12.1 & 17 & 8.86 \\
YEARS & & & & & & \\
OLD & & & & & & \\
\hline TOTAL & 93 & 100 & 99 & 100 & 192 & 100 \\
\hline
\end{tabular}

Table 7 Distribution by age ranges of the 2018 and 2019 cohort surveyed students of the Bachelor of Accounting Source: own elaboration 
Regarding gender distribution, it is observed that in both cohorts there is a majority of the female gender, of 93 people in the 2018 cycle, $50(53.8 \%)$ belong to the gender in question, for the 2019 cycle of the total of 99 people, $58(56.6 \%)$ are women, leaving the space for the male gender of $43(46.2 \%)$ and 41 (41.4\%) for 2018 and 2019 respectively. See Table 8 .

\begin{tabular}{|c|c|c|c|c|c|c|}
\hline Gender & \multicolumn{2}{|c|}{$\begin{array}{c}\text { Cycle } 2018 \\
\text { Population }\end{array}$} & \multicolumn{2}{|c|}{$\begin{array}{c}\text { Cycle } 2019 \\
\text { Population }\end{array}$} & \multicolumn{2}{|c|}{ Total } \\
\hline Man & 43 & 46.2 & 41 & 41.4 & 84 & 43.8 \\
\hline Woman & 50 & 53.8 & 58 & 56.6 & 108 & 56.2 \\
\hline TOTAL & 93 & 100 & 99 & 100 & 192 & 100 \\
\hline
\end{tabular}

Table 8 Distribution by gender of the total number of students surveyed cohorts 2018 and 2019 of the Bachelor of Accounting

Source: self made

The employment status of the students subject to study, in both cohorts the vast majority in addition to studying are already in the productive sector somehow they work on their own or have a employer, 60 (64.5\%) for the 2018 cohort and $67(67.7 \%)$ in the 2019 cohort, totaling $127(66.14 \%)$ of the respondents, consequently 33 (35.5\%) and 32 (32.3\%) respectively only study, making a total of 65 $(33.86 \%)$ between both cohorts. See table 9.

\begin{tabular}{|c|r|r|r|r|r|r|}
\hline Work & \multicolumn{2}{c}{ Cycle 2018 } & \multicolumn{2}{c|}{ Cycle 2019 } & \multicolumn{1}{c|}{ Total } \\
\hline YES & 60 & 64.5 & 67 & 67.7 & 127 & 66.14 \\
\hline NO & 33 & 35.5 & 32 & 32.3 & 65 & 33.86 \\
\hline TOTAL & 93 & 100 & 99 & 100 & 192 & 100 \\
\hline
\end{tabular}

Table 9 Employment status of the 2018 and 2019 cohort surveyed students

Source: own elaboration

\section{Results}

Based on the values of the central tendencies that represent the perception of the undergraduate students of the 2018 and 2019 cohorts of the Bachelor of Accounting in relation to the statements about the "Attitudes and beliefs towards employment", of the selected statements, the assertion of better behavior to fully agree with a central trend value of 4.5161 in the 2018 cycle is related to "Finding a job is important to me", with the difference of experiencing a decrease in perception to agree on the 2019 cycle the value of the average of 4.2222, however it remained the best qualified in both cohorts.
Secondly, in the 2018 cohort to agree is the statement "I feel qualified to look for employment", in the same way this statement obtains in the 2019 cohort a lower perception in the value of the average, staying at the level to be of agreement.

Mentioned in order of importance are the statements, "Job search techniques help to find a job", "Job search is enjoyable, stimulating and challenging.", And "I know the sources that can provide me with a job," support the Same tendency to agree on both cycles.

The following statement in order of importance to agree in the 2018 cycle, "I feel qualified to use the employment techniques properly.", Suffers a setback in 2019 in the value of its perception to neutral, the behavior of the statement, "I would like to have a paid job, even if I don't need the money." In the 2018 cohort it is neutral experiencing an improvement to agree in the following period, and finally the affirmation of worse behavior in the 2018 cycle evaluated according to the value from average to neutral it is, "Work is the most important activity of a person", showing a better acceptance in the 2019 cycle to agree.

The general behavior in the other statements in both cycles is neutral and to agree, the values of the means fluctuate between 3 and 4. See table 10.

\begin{tabular}{|l|r|r|r|}
\hline \multicolumn{1}{|c}{ Affirmation } & \multicolumn{2}{c}{$\begin{array}{l}\text { 2018 } \\
\text { average }\end{array}$} & Difference \\
\hline $\begin{array}{l}\text { As soon as I finish my degree, I } \\
\text { will look for a job. }\end{array}$ & 3.9355 & 3.5657 & -0.3698 \\
\hline $\begin{array}{l}\text { In the current economic situation } \\
\text { it is almost impossible to find a } \\
\text { job. }\end{array}$ & 3.0968 & 3.1313 & 0.0345 \\
\hline $\begin{array}{l}\text { Finding a job depends mostly on } \\
\text { the "levers." }\end{array}$ & 3.4409 & 3.4747 & 0.0339 \\
\hline $\begin{array}{l}\text { I really care what my parents } \\
\text { think about looking for a job. }\end{array}$ & 3.0323 & 3.0202 & -0.0121 \\
\hline $\begin{array}{l}\text { The job search is pleasant, } \\
\text { stimulating and challenging. }\end{array}$ & $(4) 3.6022$ & $(4) 3.6364$ & 0.0342 \\
\hline $\begin{array}{l}\text { Knowing the sources of } \\
\text { information is very useful for } \\
\text { finding employment. }\end{array}$ & 4.1075 & 4.1515 & 0.0440 \\
\hline $\begin{array}{l}\text { Job search techniques help you } \\
\text { find a job. }\end{array}$ & $(3) 3.7527$ & $(3) 3.8485$ & 0.0958 \\
\hline $\begin{array}{l}\text { I feel qualified to use the } \\
\text { employment } \\
\text { properly. }\end{array}$ & $(6) 3.5054$ & $(8) 3.3434$ & -0.1619 \\
\hline $\begin{array}{l}\text { I know the sources that can } \\
\text { provide me with a job. }\end{array}$ & $(5) 3.5161$ & $(5) 3.5657$ & 0.0495 \\
\hline $\begin{array}{l}\text { Finding a job depends mostly on } \\
\text { luck. }\end{array}$ & 2.2043 & 2.4545 & 0.2502 \\
\hline $\begin{array}{l}\text { I think finding a job depends on } \\
\text { me. }\end{array}$ & 4.2151 & 4.2525 & 0.0375 \\
\hline $\begin{array}{l}\text { My parents expect me to work } \\
\text { hard to find a job. }\end{array}$ & 4.0323 & 3.9899 & -0.0424 \\
\hline $\begin{array}{l}\text { If I had the opportunity, I would } \\
\text { look for a job. }\end{array}$ & 4.1613 & 3.8384 & -0.3229 \\
\hline
\end{tabular}

ARGÜELLES-MA, Luis Alfredo, QUIJANO-GARCIA, Román Alberto, MEDINA-BLUM, Fernando and CRUZ-MORA, Carlos Enrique. The incorporation of undergraduate academy students from a public university to the productive sector with substance in its professional competences. Journal Schools of economic Thought and Methology. 2019 


\begin{tabular}{|l|r|r|r|}
\hline $\begin{array}{l}\text { I think learning to look for work } \\
\text { is a fool's thing. }\end{array}$ & 1.6559 & 1.9394 & 0.2835 \\
\hline Finding a job is important to me. & $(1) 4.5161$ & $(1) 4.2222$ & -0.2939 \\
\hline $\begin{array}{l}\text { The job search is frustrating and } \\
\text { daunting. }\end{array}$ & 2.6774 & 3.0404 & 0.3630 \\
\hline I feel qualified to look for a job. & $(2) 3.7742$ & $(6) 3.5455$ & -0.2287 \\
\hline $\begin{array}{l}\text { A job is just a way to earn } \\
\text { money, nothing more. }\end{array}$ & 2.3441 & 2.5152 & 0.1711 \\
\hline $\begin{array}{l}\text { I would like to have a paid job, } \\
\text { even if I don't need the money. }\end{array}$ & $(7) 3.4624$ & $(2) 3.8990$ & 0.4366 \\
\hline $\begin{array}{l}\text { Work is the most important } \\
\text { activity of a person. }\end{array}$ & $(8) 3.4409$ & $(7) 3.4545$ & 0.0137 \\
\hline
\end{tabular}

Table 10 Average comparison of the dimension "Attitudes and beliefs towards employment" cohorts 2018 and 2019 Source: own elaboration

Based on the previous results, we observed that 4 statements remained constant to the degree of importance according to the perception of the respondents in both cohorts, "Finding a job is important to me", "Job search techniques help to find a job" , "The job search is pleasant, stimulating and challenging.", And "I know the sources that can provide me with a job,". The statement with the second degree of importance in the 2018 cohort, "I feel qualified to look for a job", in the 2019 cut experiences a downward trend becoming the sixth, this similarity of the downward trend is observed by the assertion " I feel qualified to use the employment techniques properly "which of the sixth in order of importance in 2018 becomes the worst qualified in 2019. Finally, the assertions that obtained a high trend are: I would like to have a paid job, even if I don't need the money ", and" Work is the most important activity of a person ", going from the seventh worst qualified in 2018 as the second better in the next cycle and from the eighth to the seventh respectively. See table 11 .

\begin{tabular}{|r|l|r|l|}
\hline 2018 & \multicolumn{1}{|c|}{ AFFIRMATION 2019} & \multicolumn{1}{|c|}{ TREND } \\
\hline 1 & Finding a job is important to me. & 1 & Constant \\
\hline 2 & I feel qualified to look for a job. & 6 & Down \\
\hline 3 & $\begin{array}{l}\text { Job search techniques help you } \\
\text { find a job. }\end{array}$ & 3 & Constant \\
\hline 4 & $\begin{array}{l}\text { The job search is pleasant, } \\
\text { stimulating and challenging. }\end{array}$ & 4 & Constant \\
\hline 5 & $\begin{array}{l}\text { I know the sources that can } \\
\text { provide me with a job. }\end{array}$ & 5 & Constant \\
\hline 6 & $\begin{array}{l}\text { I feel qualified to use the } \\
\text { employment techniques } \\
\text { properly }\end{array}$ & 8 & Down \\
\hline 7 & $\begin{array}{l}\text { I would like to have a paid job, } \\
\text { even if I don't need the money. }\end{array}$ & 2 & To the High \\
\hline 8 & $\begin{array}{l}\text { Work is the most important } \\
\text { activity of a person. }\end{array}$ & 7 & To the High \\
\hline
\end{tabular}

Table 11 Comparison of the order of importance of the Attitudes and Beliefs towards Employment dimension Cohorts 2018 and 2019

Source: own elaboration
In the table of comparison of means of the section "Professional competences" of the dimension "Orientation of labor advice and transversal competences" of the bachelor's degree in accounting cohorts 2018 and 2019, we observe that the one of best behavior to a great importance, according to the perception of Undergraduate students 2018 is the competition related to "Interpreting financial information for management decision making" which is perceived as quite important occupying the second seat for 2019; "Applying the financial information standards (national and international)" is quite important for both cycles, second best evaluated in the 2018 cycle, behavior similar to the previous competition losing a place in the 2019 cycle when occupying the third place of importance, trend that changes in the competition "Interpret properly the fiscal norms applicable to natural and moral persons with the purpose of contributing to the fulfillment of said precepts." Evaluated in both cycles with considerable importance, occupying the third best position in 2018, becoming the better qualified with respect to the value of its central tendency in the following cycle. The worst qualified competition giving it some importance in the perception of students in both cohorts is "Establish actions for knowledge assessment, application of the different options available for the registration and control of the treasury."

In general, both cycles, with the exception of the aforementioned competition that was rated with some importance, the remaining professional competences (12 in total) have a perception with respect to the value of their means in a range of quite and very important agreement to the value of the scales established for this analysis. See table 12.

\begin{tabular}{|l|r|r|r|}
\hline \multicolumn{1}{|c|}{ Items } & Mean 2018 & \multicolumn{1}{c|}{$\begin{array}{l}\text { Mean } \\
\mathbf{2 0 1 9}\end{array}$} & Difference \\
\hline $\begin{array}{l}\text { 1.-Design, operate and value } \\
\text { financial information systems }\end{array}$ & 4.3441 & 4.2727 & -0.0714 \\
\hline $\begin{array}{l}\text { 2-Interpret financial information for } \\
\text { management decision making. }\end{array}$ & 4.5484 & 4.4848 & -0.0635 \\
\hline $\begin{array}{l}\text { 3.-Design accounting procedures } \\
\text { and internal control processes. }\end{array}$ & 4.4301 & 4.3434 & -0.0867 \\
\hline $\begin{array}{l}\text { 4.- Design to operate and value } \\
\text { accounting systems }\end{array}$ & 4.4731 & 4.4141 & -0.0590 \\
\hline $\begin{array}{l}\text { 5.-Adapt the processes for the } \\
\text { knowledge, evaluation and } \\
\text { application of the different working } \\
\text { capital financing alternatives }\end{array}$ & 4.0753 & 4.4343 & 0.3591 \\
\hline $\begin{array}{l}\text { 6.-Establish actions for knowledge } \\
\text { assessment, application of the } \\
\text { different options available for the } \\
\text { registration and control of the } \\
\text { treasury. }\end{array}$ & 3.9892 & 3.8283 & -0.1610 \\
\hline $\begin{array}{l}\text { 7.- Design to implement and operate } \\
\text { different kinds of cost control. }\end{array}$ & 4.0753 & 4.0101 & -0.0652 \\
\hline $\begin{array}{l}\text { 8.-Perform financial audits and } \\
\text { issue opinions }\end{array}$ & 4.1290 & 4.2020 & 0.0730 \\
\hline
\end{tabular}

ARGÜELLES-MA, Luis Alfredo, QUUJANO-GARCIA, Román Alberto, MEDINA-BLUM, Fernando and CRUZ-MORA, Carlos Enrique. The incorporation of undergraduate academy students from a public university to the productive sector with substance in its professional competences. Journal Schools of economic Thought and Methology. 2019 


\begin{tabular}{|l|r|r|r|}
\hline $\begin{array}{l}\text { 9.-Analyze and interpret cost } \\
\text { information }\end{array}$ & 4.2151 & 4.4242 & 0.2092 \\
\hline $\begin{array}{l}\text { 10.- Perform financial tax planning } \\
\text { of organizations }\end{array}$ & 4.3548 & 4.2929 & -0.0619 \\
\hline $\begin{array}{l}\text { 11.- Apply the financial information } \\
\text { standards (national and } \\
\text { international) }\end{array}$ & 4.4839 & 4.4646 & -0.0192 \\
\hline $\begin{array}{l}\text { 12.-Properly interpret the tax } \\
\text { regulations applicable to natural and } \\
\text { legal persons with the purpose of } \\
\text { contributing to the fulfillment of } \\
\text { said precepts. }\end{array}$ & 4.4731 & 4.5357 & 0.0626 \\
\hline $\begin{array}{l}\text { 13.-Deepen and facilitate the } \\
\text { adoption and technological } \\
\text { innovation research processes to } \\
\text { increase the productivity and } \\
\text { competitiveness of companies }\end{array}$ & $(8) 4.3011$ & & \\
\hline
\end{tabular}

Table 12 Comparison of means resulting from the "Professional competencies" section of the "Employment counseling and transversal competencies" dimension cohorts 2018 and 2019

Source: own elaboration

Comparing the order of importance of the "Professional competencies" section of the "Employment counseling and transversal competencies" dimension between both cohorts, 9 of the 13 professional competences maintain a downward trend, being the most important for the 2018 cycle "Interpreting financial information for managerial decision making "moving to second term in the 2019 cycle, the second most important in the 2018 cohort" Applying financial information standards (national and international) "also keeps the downward trend at to become the third in importance in the following cohort, contrary to professional competence "Properly interpret the tax rules applicable to natural and moral persons with the purpose of contributing to the fulfillment of these precepts" becomes the third most important in the year 2018 to the first in the year of 2019, others competences that maintain this improvement behavior are "Analyze and interpret information on costs" from the ninth position to the fifth and "Adapt the processes for the knowledge, evaluation and application of the different alternatives for financing working capital" of the tenth second fourth position; the only competition that maintains a constant behavior is "Deepen and facilitate the adoption and technological innovation research processes to increase the productivity and competitiveness of companies" with a value of its central tendency between 3 and 4 (something and a lot) therefore turning out to be the worst rated in order of importance in both cycles. Even with the behavior of the downward trend value in the order of importance of professional competencies, most remain in the range between 4 (quite) and 5 (much), except for the one mentioned in the last instance. See table 13.

\begin{tabular}{|c|c|c|c|}
\hline 2018 & $\begin{array}{l}\text { PROFESSIONAL } \\
\text { COMPETITION }\end{array}$ & 2019 & TREND \\
\hline 1 & $\begin{array}{l}\text { Interpret financial information } \\
\text { for management decision } \\
\text { making }\end{array}$ & 2 & Down \\
\hline 2 & $\begin{array}{lrr}\begin{array}{l}\text { Apply financial reporting } \\
\text { standards } \\
\text { (national }\end{array} & \text { and } \\
\text { international) } & & \\
\end{array}$ & 3 & Down \\
\hline 3 & $\begin{array}{l}\text { Properly interpret the tax } \\
\text { regulations applicable to natural } \\
\text { and legal persons with the } \\
\text { purpose of contributing to the } \\
\text { fulfillment of said precepts. }\end{array}$ & 1 & To the High \\
\hline 4 & $\begin{array}{l}\text { Design to operate and value } \\
\text { accounting systems }\end{array}$ & 6 & Down \\
\hline 5 & $\begin{array}{l}\text { Design accounting procedures } \\
\text { and internal control processes. }\end{array}$ & 7 & Down \\
\hline 6 & $\begin{array}{l}\text { Perform financial tax planning } \\
\text { of organizations }\end{array}$ & 8 & Down \\
\hline 7 & $\begin{array}{l}\text { Design, operate and value } \\
\text { financial information systems }\end{array}$ & 9 & Down \\
\hline 8 & $\begin{array}{l}\text { deepen and facilitate the } \\
\text { adoption and innovation } \\
\text { research processes }\end{array}$ & 10 & Down \\
\hline 9 & $\begin{array}{l}\text { Analyze and interpret cost } \\
\text { information }\end{array}$ & 5 & To the High \\
\hline 10 & $\begin{array}{l}\text { Perform financial audits and } \\
\text { issue opinions }\end{array}$ & 11 & Down \\
\hline 11 & $\begin{array}{l}\text { Design to implement and } \\
\text { operate different kinds of cost } \\
\text { control. }\end{array}$ & 12 & Down \\
\hline 12 & $\begin{array}{l}\text { Adapt the processes for the } \\
\text { knowledge, evaluation and } \\
\text { application of the different } \\
\text { working capital financing } \\
\text { alternatives }\end{array}$ & 4 & To the High \\
\hline 13 & $\begin{array}{l}\text { Deepen and facilitate the } \\
\text { adoption and technological } \\
\text { innovation research processes to } \\
\text { increase the productivity and } \\
\text { competitiveness of companies }\end{array}$ & 13 & Constant \\
\hline
\end{tabular}

Table 13 Comparison of the order of importance of the "Professional competencies" section of the "Labor counseling and transversal competencies" dimension of the Bachelor of Accounting cohorts 2018 and 2019 Source: own elaboration

\section{Conclusion}

In accordance with the results for undergraduate students, objects of the study in both cohorts, they affirm that the acquisition of professional competences, learned in their academic training, is adequate because they have a fairly acceptable degree of approval in 12 professional competences of the 13 in total evaluated, but not in references to attitudes and beliefs towards employment where the general precept is very low in both cycles, this result could be consistent among other factors that in both cohorts the average $68 \%$ of students on stage Academic are already in the productive apparatus either self employed or working for an employer. As mentioned at the beginning of this section, professional competences were well evaluated in both cohorts, maintaining a downward acceptance trend from one cycle to another, and one of them is practically not very accepted, they are not interested in being employed.

ARGÜELLES-MA, Luis Alfredo, QUUJANO-GARCIA, Román Alberto, MEDINA-BLUM, Fernando and CRUZ-MORA, Carlos Enrique. The incorporation of undergraduate academy students from a public university to the productive sector with substance in its professional competences. Journal Schools of economic Thought and Methology. 2019 
In research activities to increase the productivity and competitiveness of companies, you agree that in the labor context of our environment there are no companies that offer this type of work. In order to change the downward trend of professional competencies in general and improve the panorama of students when they graduate with respect to their integral labor insertion, interdisciplinary collaboration in universities and interuniversity is necessary, as well as working together with the world business in an effective way to generate potential that helps improve the "employability" of our university students.

The objective of the research work is fulfilled by contributing to the semblance of the situation of the graduates of the Bachelor of Accounting of a Public University, where it is visualized that the necessary changes are being made in the teaching platforms so that they are well supported and They can successfully enter the productive society. It is satisfactory to see that the university under investigation is on par with the globalization process, with the details determined but that are minimal compared to the efforts being made.

\section{References}

Argundin, Y. (2007), Educación basada en competencias, Trillas, México.

Arnau, Jaume y Bono, Roser (2008) Estudios longitudinales. Modelos de diseño y análisis. Escritos de Psicología. ISSN: 1138-2635. Disponible en: http://www.redalyc.org/articulo.oa?id=2710/27 $1020194005</ a$

Bisquerra, R. (1992). Orientació psicopedagògica i desenvolupament de recursos humans. Barcelona: La Llar del Llibre.

Blanco, J. (2005). El Prácticum en los Estudios Pedagógicos.

Fournet, M. (1993). S'inserer par le diplôme ou l'experience? Etude exploratoire des représentations des jeunes 16-25 ans entrés en C.F.I. L'Orientation Scolaire et Professionnelle, 4, 27, 351-361.
Hernández, Roberto; Fernández-Collado, Carlos; Pilar Baptista, Lucio. (2010). Metodología de la Investigación. México: McGraw-Hill. sexta edición

Ibarra, A. (2000) Formación de recursos humanos y competencia laboral, Boletín Cinterfor, (149), 95-107.

Leboyer, L (1997). Gestión de las Competencias. Barcelona: Gestión 2000.

Mertens, L. (1998) La gestión por competencia laboral en la empresa y la formación profesional, Madrid, OEI.

Myers, D. (2006), Psicología 7ma edición. Editorial Médica Panamericana:Madrid

Tejada, J. (1999). Acerca de las competencias profesionales. Revista Herramientas (I), núm. 56 (pp. 20-30) y (II) 57 (8-14)

Verdejo, P. (2006) Modelo para la Educación y Evaluación por Competencias (MECO), México.

Visser, R. A. (1985). Analysis of longitudinal data in behavioural and social research. Leiden: DSWO Press. 